\title{
Causality Analysis of the Impact of Foreign Direct Investment on GDP in Nigeria.
}

\author{
${ }^{1}$ A.Z. Faruku, ${ }^{2}$ B.K. Asare, ${ }^{2}$ M. Yakubu and ${ }^{1}$ L. Shehu \\ ${ }^{1}$ Dept. of Mathematics and Computer Science, Waziri Umaru Federal polytechnic, Birnin Kebbi. \\ ${ }^{2}$ Department of Mathematics, Usmanu Danfodiyo University, Sokoto \\ [Corresponding Author: ykmtm2000@yahoo.com]
}

ABSTRACT: This study used a Cointegration VAR model to study the Contemporaneous Long ï run dynamics of the impact of foreign direct Investment (FDI) on Growth Domestics Products (GDP) with other four macroeconomic variables in the Nigerian Economy for the period of January 1970 to December 2004. The Unit Root Test suggests that all the variables are integrated of order 1. The VAR (3) model were appropriately Identified using AIC information criteria and the VECM (2) model with cointegration relation of exactly one. The study further investigate the causal relationship using the Granger Causality analysis of VECM which indicates a uniï directional causal relationship between GDP and FPI at 5\% as in inline with other studies of Basu et al.(2003). The results of Granger Causality Analysis also show that some of the variables are Granger Causal of one another, at 5\% level of significance. Having established the fact that foreign direct investment has positive impact on growth domestic product, government should strategize policies that would enhance foreign direct investment in Nigeria.

Key Words: Cointegration, VAR, VECM, and Granger Causality

\section{INTRODUCTION}

The introduction of co integration techniques in modeling and analyzing macro economics variables has tremendously changed the nature and direction of modeling of macro economics system (or sub systems). It provides an alternative means to assess the extent to which the variables under consideration are integrated. Specifically, if GDP, FDI and four other macro economic variables are integrated of order one, then, they will be cointegrated or have a long run equilibrium relationship. The co integration relations are used as a tool for discussing the existence of long-run economic relations and various hypotheses are then tested in view of the statistical variations of the data. The use of Vector Autoregressive Models (VAR) and Vector Error Correction Models (VECM) for analyzing dynamic relationships among financial variables has become common in the literature, (Granger 1981; Engle and Granger, 1987; MacDonald and Power, 1995; Barnhill, et al., 2000).The popularity of these models has been associated with the realization that relationships among financial variables are so complex that traditional time-series models have failed to fully capture.

The manifestation of economic crises in most of developing countries including Nigeria in the late 1970s and early 1980s made the authorities of these countries to change their attention toward macro economic policy and its relation to economic growth by increasing effort toward attracting foreign direct investment (Adeolu, 2007). Caves (1996) observes that the rationale for increased efforts to attract more FDI stems from the belief that FDI has several positive effects. Among these are productivity gains, technology transfers, and the introduction of new processes, managerial skills and know-how in the domestic market, employee training, international production networks, and access to markets. However, there have been some studies on investment and growth in Nigeria with varying results and submissions. Ariyo (1998) studied the investment trend and its impact on Nigeriaô economic growth over the years. He found that only private domestic investment consistently contributed to raising GDP growth rates during the period considered (1970ï 1995). Furthermore, there is no reliable evidence that all the investment variables included in his analysis have any perceptible influence on economic growth. He therefore suggests the need for an institutional rearrangement that recognizes and protects the interest of major partners in the development of the economy. Oyinlola (1995) conceptualized foreign capital to include foreign loans, direct foreign investments and export earnings. Adelegan (2000) explored the seemingly unrelated regression model to examine the impact of FDI on economic growth in Nigeria and found out that FDI is pro-consumption and pro-import and negatively related to gross domestic investment. 
Akinlo (2004) found that foreign capital has a small and not statistically significant effect on economic growth in Nigeria.

The objective of this study is, therefore to conduct Engle Granger Causality test to investigate the impact of foreign direct investments on gross domestic product in Nigeria, using Vector error correction Model (VECM) techniques.

Review of the causal Relationship between FDI and GDP: One of the most important concepts of causality was introduced by Granger (1969) and has become quite popular in the economic literature. This study specifically is interested in the literature that focused more directly on the causal relationships between FDI and growth and, at least, six studies have tested for Granger causality between the two series using different samples and estimation techniques. Zhang (2001) looks at 11 countries on a country-by-country basis, dividing the countries according to the time series properties of the data. Tests for long run causality based on an error correction model, indicate a strong Granger-causal relationship between FDI and GDP-growth. For six counties where there is no cointegration relationship between the $\log$ of FDI and growth, only one country exhibited Granger causality from FDI to growth. Chowdhury and Mavrotas (2003) take a slightly different route by testing for Granger causality using the Toda and Yamamoto (1995) specification, thereby overcoming possible pretesting problems in relation to tests for cointegration between series. Using data from 1969 to 2000, they find that FDI does not Granger cause GDP in Chile, whereas there is a bi-directional causality between GDP and FDI in Malaysia and Thailand.

Finally the study by Basu et al. (2003) addresses the question of the two-way link between growth and FDI. Allowing for country specific cointegrating vectors as well as individual country and time fixed effects they find a cointegrated relationship between FDI and growth using a panel of 23 countries. Basu et al. emphasize trade openness as a crucial determinant for the impact of FDI on GDP; they find two-way causality between FDI and growth in open economies, both in the short and the long run, whereas the long run causality is unidirectional from GDP to FDI in relatively closed economies.

\section{MATERIALS AND METHODS}

The detailed overview of procedures and methodology to be implemented in this research work is hereby presented. The theoretical model, which also serves as a basic frame work of our statistical analysis, is the Vector Autoregressive model of order $\mathrm{p}$, which is denoted by VAR (P) and is given by $Y_{t}=\partial+D_{t}+\psi+\phi_{1} Y_{t-1}+\phi_{2} Y_{t-2}+\ldots+\phi_{p} Y_{t-p}+\varepsilon_{t}$ (2.1)

Equation (2.1) can be written as $\phi(L) Y_{t}=\partial+D_{t}+\psi+\varepsilon_{t}$

Where $\phi(L)=1-\sum_{j=1}^{n} \phi_{j} L^{j}$, $\mathrm{Y}_{t}=\left(\mathrm{Y}_{1 t}, \mathrm{Y}_{2 t} \ldots, \mathrm{Y}_{k t}\right)^{\prime}$ is a set of $\mathrm{k}^{\text {th }}$ time series variables , $\partial$ is the constant term, $\mathrm{D}_{t}$ is the regressors associated with deterministic terms, $\psi$ is the seasonal dummies and structural breaks and $\varepsilon_{t}=\left(\varepsilon_{1 t}, \varepsilon_{2 t}, \ldots, \varepsilon_{k t}\right)^{\prime} \quad$ is an unobserved zero means independent white noise process with time invariant and positive definite covariance matrix $\mathrm{E}\left(\varepsilon_{t} \varepsilon_{t}^{\prime}\right)=\Sigma_{k} \quad$ and $\phi(L)=1-\phi_{1} L-\phi_{2} L^{2}-\ldots-\phi_{p} L^{P}$ is a matrix of a lag polynomial with $\mathrm{kxk}$ coefficient matrices, $\phi_{j}, \mathrm{j}=1,2, \ldots, \mathrm{p}$.

When interest centre on cointegration relation the more convenient model to use is Vector Error Correction model (VECM) which is given by:

$\Delta y_{t}=\pi y_{t-1}+\Gamma_{1} \Delta y_{t-1}+\ldots+\Gamma_{p-1} \Delta y_{t-p+1}+\partial+D_{t} \psi+\varepsilon_{t}$

Where $\pi=-\left(\mathrm{I}_{n}-\phi_{1}-\phi_{2}-\ldots-\phi_{p}\right) \quad$ and $\Gamma_{j}=-\left(\phi_{i+1}+\ldots+\phi_{p}\right)^{\prime}$ for $(\mathrm{i}=1,2, \ldots, \mathrm{p}-1)$

Since $\Delta Y_{t}$ does not contain stochastic treads by our assumption that all variances should be I(1), the mean term $\pi X_{t-1}$ is the only one which includes $\mathrm{I}(1)$ variables. Hence, $\pi Y_{i-1}$ must also beI (0) thusit contain the cointegration relations. The $\Gamma_{j}(\mathrm{j}=1,2, \ldots, 1-\mathrm{p})$ are often referred as the short run term while $\pi Y_{t-1}$ is sometimes called the long run term. The model in (2.2) is abbreviated as VECM (P-1). 
Unit Root and Stationarity Tests: Quite a number of unit root test have been developed with a view to determining whether the series are stationary, in this research we consider two tests that test the null hypothesis of Unit Root against the alternative of stationary. These are: Augmented Dickey- Fuller (ADF) Unit Root Test and the Dickey Fuller-Generalized Least Square (DF-GLS) Test. And KPSS Test with the null hypothesis of Stationarity against alternative of Unit Root.

VAR Lag Order by Selection Criterion and Cointegration Test: The following criteria are often used:

(i) This is the Akaike information criterion Akaike. (1974)

$$
A I C=\ln \frac{1}{T} \sum_{t=1}^{T}\left(\hat{u}_{t}^{(p)}\right)^{2}+m \frac{2}{T}
$$

(ii) Alternatives are the Bayesian criterion of Gideon (1978)

$$
S C=\ln \frac{1}{T} \sum_{t=1}^{T}\left(\hat{u}_{t}^{(p)}\right)^{2}+\mathrm{m} \frac{\ln T}{T}
$$

(iii) the criterion developed by Edward and Quinn (1979)

$$
H Q=\ln \frac{1}{T} \sum_{t=1}^{T}\left(\hat{u}_{t}^{(p)}\right)^{2}+\mathrm{m} \frac{2 \ln (\ln T)}{T}
$$

There are several methods available for conducting the cointegration test. The most widely used methods include the residual based Engle and Granger (1987) test and Maximum likelihood base Johansen (1991) test.

Model Checking: Once a model has been specified its adequacy is usually checked with a series of tests. There is need to implement some of the statistic test in order to obtain valid and accurate results. Most of these model checking tools are based on the residuals of the model. These includes: Autoregressive Condition Heteroskedastic-Lagrange Multiplier (Arch ï Lm), Breusch ï Godfrey Lagrange Multiplier (Lm) Test, Portmanteau Test for Autocorrelation, and Jarque- Bera Test of Normality.
Stability Analysis: Parameters are constant through out the sample period, is a key assumption in econometric models. In this study the recursive residuals test that is CUSUM TEST are adopted to check the validity of this assumption.

The Cusum Test: The Cusum test according to Brown et al. (1975) cited in Lutkepohl et al. (2005) is based on the cumulative sum of recursive residuals. The test plots the cumulative sum together with the $95 \%$ critical line.

The test finds parameter instability if the cumulative sum goes outside the area between the two critical lines, up to a particular period t.

$$
\text { CUSUM }=\sum_{r=k+1}^{T} \frac{W_{r}}{S}, \quad \mathrm{r}=k+1, \ldots, T
$$

Where $\mathrm{W}$ is the recursive model, $\mathrm{s}$ is the standard error of the regression fitted to all $\mathrm{T}$ sample point, $\mathrm{k}$ is the number of coefficient to be estimated.

The significance of any departure from the zero line is assessed by reference to a pair of $95 \%$ significance lines. The distance which increases with Movement $w_{r}$ outside the critical lines is suggesting coefficient instability.

On the other hand the CUSUM square test is based on the statistic

$$
\text { CUSUM }-S Q=\frac{\sum_{r=k+1}^{T} w_{r}^{2}}{\sum_{r=k+1}^{T} w_{r}^{2}}
$$

If the CUSUM ï SQ cross the pair of 95\% critical lines it indicate the structural instability.

The Granger Causality Analysis: The causality concept introduce by Granger (1969) is perhaps the most widely discussed form of causality in the econometrics literatures, Granger defines a variable $y_{t}$ to be cause by another time series variables $x_{t}$ if the former variables can be predicted using past values of $x_{t}$ in addition to the all other relevant information needless to say, the correct estimation procedure would be to include all 
independent variables indicated by the relevant economic theory.

Excluding appropriate variables may yields irrelevant and useless results. Granger considers a system of the general form.

$\left(\begin{array}{l}y_{1 t} \\ y_{2 t}\end{array}\right)=C D_{t}+\sum_{t=1}^{p}\left(\begin{array}{ll}\alpha_{11} & \alpha_{12} \\ \alpha_{21} & \alpha_{22}\end{array}\right)\left(\begin{array}{l}y_{1 t-1} \\ y_{2 t-1}\end{array}\right)+\left(\begin{array}{l}u_{1 t} \\ u_{2 t}\end{array}\right)$

In the model set up, $y_{1 t}$ does not Granger cause $y_{2 t}$ if and only if

$\alpha_{2 i}=0, \quad \mathrm{i}=1,2, \ldots, \mathrm{p}$

In other words, $y_{t}$ Granger cause $x_{t}$ if $y_{t}$ can help forecast $x_{t}$. if $y_{t}$ does not cause $x_{t}$ and $x_{t}$ does not cause $y_{t}$ then both $y_{t}$ and $x_{t}$ are independent if $y_{t}$ cause $x_{t}$ and $x_{t}$ cause $y_{t}$, it said that feedback exist between $x_{t}$ and $y_{t}$.

A Wald test statistic divided by the number of restriction is used in conjunction with an Fdistribution for testing the restriction (Lueikepohl (1991). If the F- statistic is greater than the critical value for an $\mathrm{F}$ ï distribution, then null hypothesis is rejected, that $y_{t}$ does not Granger cause $x_{t}$. The role of $y_{t}$ and $x_{t}$ can reverse to test Granger causality from $x_{t}$ to $y_{t}$.

If the time series variable are not stationary but integrated of the same order that is I(1) and cointegrated. Granger causality is implemented by specifying PH order VECM follows.

$$
\left(\begin{array}{c}
\Delta X_{t} \\
\Delta Y_{t}
\end{array}\right)=\left(\begin{array}{l}
\beta_{1} \\
\beta_{2}
\end{array}\right)+\sum_{t=1}^{p}\left(\begin{array}{ll}
\alpha_{11} & \alpha_{12} \\
\alpha_{21} & \alpha_{22}
\end{array}\right)\left(\begin{array}{c}
\Delta X_{t-1} \\
\Delta Y_{t-1}
\end{array}\right)+\Pi\left(\begin{array}{c}
X_{t-1} \\
Y_{t-1}
\end{array}\right)+\left(\begin{array}{l}
u_{1 t} \\
u_{2 t}
\end{array}\right)
$$

Where $\left(\begin{array}{c}X_{t-1} \\ Y_{t-1}\end{array}\right)$ is an error correction term drive from long run cointegrating relation ship, $u_{1 t}$ and $u_{2 t}$ are serially independent errors with mean zero and finite covariance matrix $\sum x$. The decision criteria is that accept $H_{0}$ (no causal relation ship between variables) if $\mathrm{p} \ddot{\mathrm{i}}$ value is greater than the significance level, otherwise we reject the null- hypothesis and accept the alternative hypothesis (there exist causal relationship between variables) if $\mathrm{p} \ddot{\mathrm{i}}$ value is less than significance level $\alpha$.

Data Analysis: Our target in this paper is to establish whether there is causality relation ship between the Gross domestic product (GDP) and Foreign direct investment in Nigeria(the emphasis is on GDP and FDI). The data for the analysis consist of annual observations of six macro economic variables in the Nigerian economy for the period of 1970 ï 2004: IFR = Inflation rate (measure by consumer price index), FDI= Foreign Direct investment, GDP= Real Gross domestic product, INR $=$ Interest rate, $\mathrm{COP}=$ Crude oil production, $\mathrm{ENC}=$ Energy consumption, obtained from the central bank of statistical bulletin vol. 16, 2005 for the period of 1970 ï 2004. Two statistical softwares are used for the empirical data analysis namely Gretl and Jmulti.

Time Plot of the Variables: The time series plot of all the variables are carried out where by each variable is plotted against time. These plots are shown in Figures 1 and 2. These plots were then examined (as we can see the entire plots have no seasonality), the variables are not covariance stationary. The plots of two variables are trending up ward. We take the log in order to stabilize their variances (GDP=1_GDP, FDI=1_FDI). The plot of the variables shows that the series are not mean reverting. 
ENC

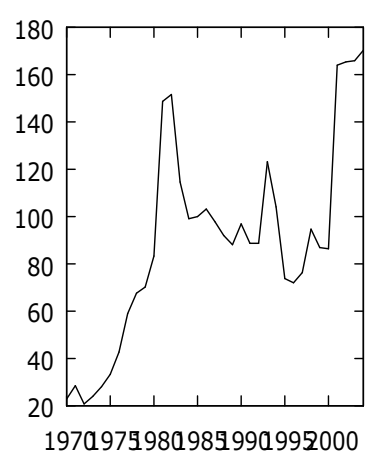

d_ENC

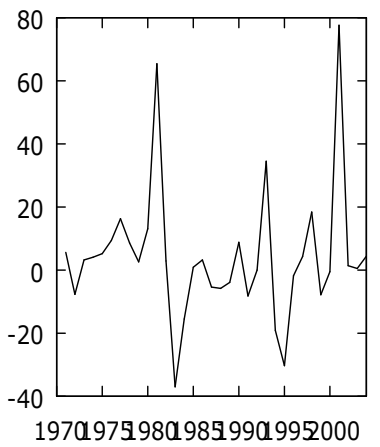

I_GDP

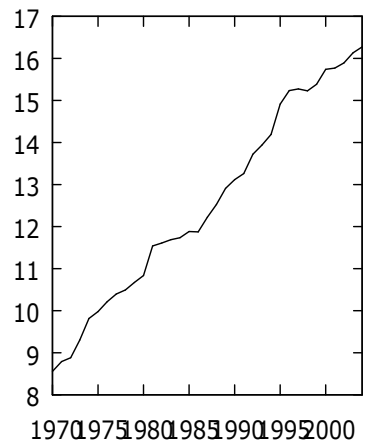

d_I_GDP

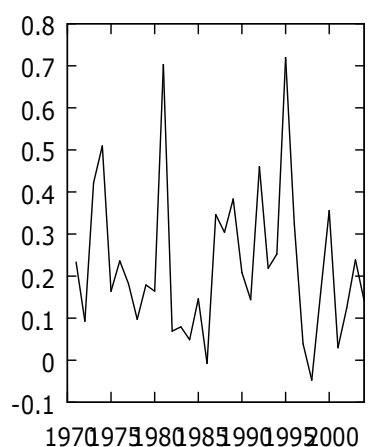

I_FPI

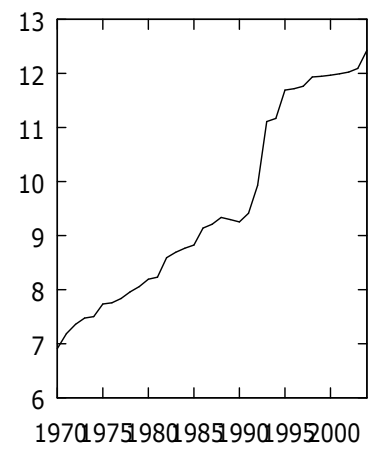

d_I_FPI

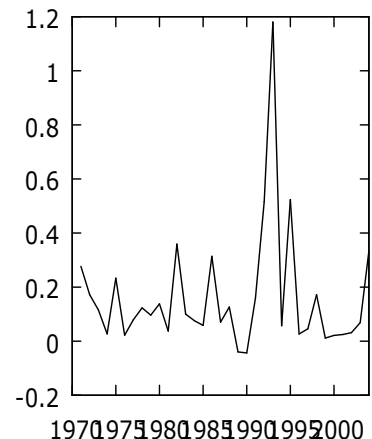

Fig. 1: Plots of Variables at Levels and First Difference
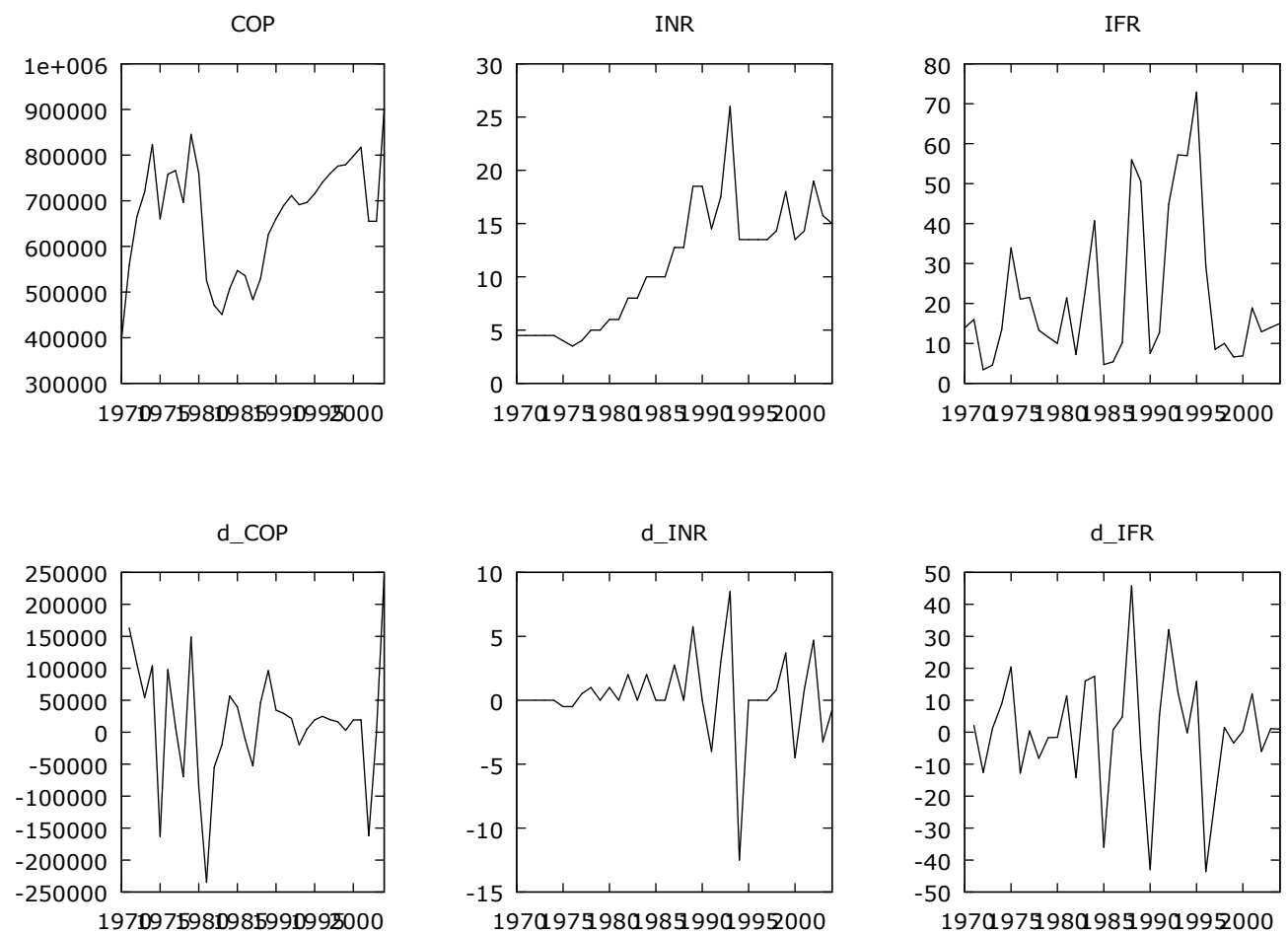

Fig. 2: Plots of Variables at levels and First Difference 
Determination the Lag Order of the Variables: In this study the ADF test down procedure is applied to determine the lag order of each variable, the maximum lag of 10 to 1 is used in this study. The results are as in Table 1.

Variable IFR has Lag order of 1 for it to be stationary in the unit root test. The variable $\log$ GDP has Lag order of 0 for it to be stationary in the unit root test. The variable log FPI has Lag order of 0 for it to be stationary in the unit root test. The variable INR has lag order of 1 for it to be stationary. Variable COP has lag order of 0 and 3 for it to be stationary in the unit root test. Variable ENC has lag order of 1 for it to be stationary in the unit root test.
Unit Root Test: Tables 1 and 2 summarize the results of unit root test. From the results, all the variables are non stationary at levels but stationary in the first difference since critical values are less than test statistics at the levels but critical values are greater than test statistics in the first difference for both ADF and ADF GLS test leading to non rejection of null hypothesis at these levels but null hypothesis is rejected at first difference. Hence the series are integrated of order one (1). Also KPSS test (Table 3) reject the null hypothesis at levels but null hypothesis is accepted at first difference

Table 1: The ADF unit root test for identification of order of integration of the variables

\begin{tabular}{|c|c|c|c|c|}
\hline \multicolumn{2}{|l|}{ Level } & & \multicolumn{2}{|c|}{ First Difference } \\
\hline Var Trend & t $і ̈$ stat Const & Const \& & Const & Const \&Trend \\
\hline 'IFR & -3.2624 & -3.2260 & -5.7776 & -5.6907 \\
\hline LnGDP & -0.7291 & -2.1934 & -5.1590 & -5.159 \\
\hline LnFPI & -0.0954 & -1.7290 & -4.7923 & -4.7357 \\
\hline INR & -1.8609 & -3.2548 & -7.1167 & -7.0088 \\
\hline COP & -2.4934 & -2.1525 & -5.6342 & -5.6342 \\
\hline ENC & -1.3000 & 1.9990 & -5.118 & -5.0289 \\
\hline Critical Val 5\% & -2.93 & -3.50 & -2.93 & -3.50 \\
\hline $1 \%$ & -3.58 & -4.15 & -3.58 & -4.15 \\
\hline
\end{tabular}

Table 2: ADF- GLS Test for identification of order of integration

\begin{tabular}{lcl|ll}
\hline \multicolumn{2}{c|}{ Levels } & \multicolumn{3}{c}{ First Difference } \\
\hline VAR Trend & Const & Const \& & Const Treand & Const \& \\
IFR & -3.1891 & - & -5.7694 & -5.7887 \\
3.2775 & & & -5.2826 & -5.3260 \\
Log GDP & 1.4291 & - & -4.6547 & -4.8491 \\
2.2999 & & & -7.2026 & -7.2117 \\
Log FPI & 1.0748 & - & -3.4319 & -4.5854 \\
1.7245 & & & & \\
INR & -1.0989 & -2.5832 & -5.2063 & -5.2090 \\
COP & -1.6238 & - & & \\
2.3861 & & & & \\
ENC & -1.0471 & - & & \\
2.3893 & & & -3.58 & -3.46 \\
$5 \%$ & -3.58 & - & -2.93 & -3.77 \\
3.46 & & & & \\
$1 \%$ & -2.91 & - & & \\
3.77 & & &
\end{tabular}


Table 3: KPSS Unit Root Test for identification of order of integration

\begin{tabular}{|c|c|c|c|c|}
\hline \multicolumn{3}{|c|}{ levels } & \multicolumn{2}{|c|}{ First Difference } \\
\hline Var & Const & Const \& Trend & Const & Const \& Trend \\
\hline IFR & 0.30011 & 0.203227 & 0.0320449 & 0.0267881 \\
\hline LnGDP & 1.81737 & 0.186698 & 0.07132249 & 0.0598517 \\
\hline LnFPI & 1.8356 & 0.217995 & 0.091847 & 0.069839 \\
\hline INR & 1.46294 & 0.230544 & 0.0810536 & 0.0527462 \\
\hline $\mathrm{COP}$ & 0.914337 & 0.202979 & 0.0862713 & 0.0861209 \\
\hline $\mathrm{ENC}$ & 1.01505 & 0.299511 & 0.0661834 & 0.0709819 \\
\hline $\begin{array}{l}\text { Critical val. } \\
5 \%\end{array}$ & 0.463 & 0.146 & 0.463 & 0.146 \\
\hline
\end{tabular}

VAR Model Identification

We estimate VAR model of 1_GDP, IFR, 1_FDI, INR, COP and ENC. With number of lags order of 3 bases on information criteria the values of AIC, HQC, and BIC are given by the result in Table 4. VAR system, maximum lag order 3 , the asterisks below indicate the best (that is, minimized) values of the respective information criteria, $\mathrm{AIC}=$ Akaike criterion, $\mathrm{BIC}=$ Schwartz Bayesian criterion and $\mathrm{HQC}=$ Hannan-Quinn criterion.

Table 4: Lag order selection

\begin{tabular}{llllll}
\hline lags & loglik & $\mathrm{p}(\mathrm{LR})$ & $\mathrm{AIC}$ & $\mathrm{BIC}$ & $\mathrm{HQC}$ \\
\hline 1 & -718.86004 & & 47.553753 & $49.477531^{*}$ & 48.191431 \\
2 & -672.06921 & 0.00000 & 46.879326 & 50.452057 & 48.063585 \\
3 & -609.71422 & 0.00000 & 45.232139 & 50.453823 & $46.962979 *$ \\
& & & $*$ & \\
\hline
\end{tabular}

We use AIC Criteria to obtain the most parsimonious model for the data. After determining the order of VAR model the next stage consist of determining the inclusion or exclusion of the constant matrices $\partial, D_{t}$ and $\psi$ as in the following model.

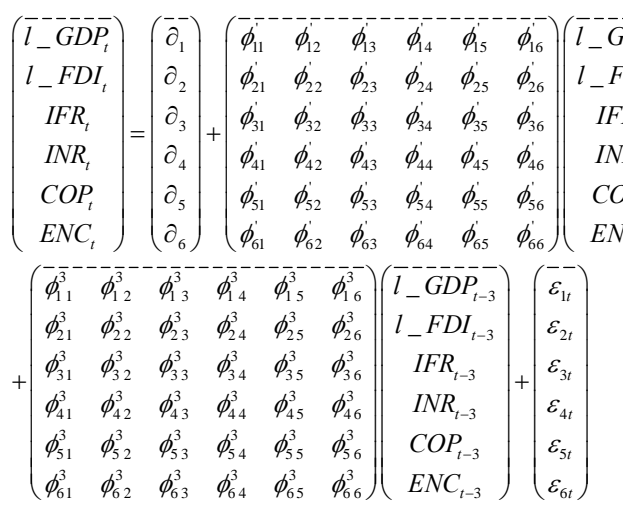

From the model above, we note that in this model (i) there are no exogenous variables, (ii) there is a constant term but no trend or dummy variables for either seasonality or structural breaks and (iii) the number of endogenous lag is 3. The absence of dummy variables is easily explain; tests shows that (a) the periodicity of the macroeconomic variables is 1 and (b) there are no structural breaks in the data. Hence, structural breaks and seasonal dummies should not be included in the VAR model.

Johansen Test for Cointegration Rank: We have applied Johansen trace test and maximum likelihood max test in order to determine the Cointegration rank of our variables since it is one of the conditions to model with VECM that there must be Cointegration relationship. The results for the test are presented in the Table 5. 
Table 5: Johanson Test for cointegration rank

\begin{tabular}{|c|c|c|c|c|}
\hline Rank & Eigenvalue & $\begin{array}{l}\text { Trace } \\
\text { test }\end{array}$ & $\begin{array}{l}\text { p- } \\
\text { value }\end{array}$ & $\begin{array}{l}\text { Lmax } \\
\text { test } \\
\text { p-value }\end{array}$ \\
\hline 0 & 0.83389 & 124.03 & 0.0001 & $\begin{array}{l}59.238 \\
0.0000\end{array}$ \\
\hline 1 & 0.64887 & 64.793 & 0.1167 & $\begin{array}{c}34.538 \\
0.0377\end{array}$ \\
\hline 2 & 0.35786 & 30.255 & 0.7076 & $\begin{array}{c}14.617 \\
0.7761\end{array}$ \\
\hline 3 & 0.25813 & 15.638 & 0.7424 & $\begin{array}{c}9.8534 \\
0.7601\end{array}$ \\
\hline 4 & 0.13426 & 5.7843 & 0.7229 & $\begin{array}{c}4.7578 \\
0.7707\end{array}$ \\
\hline 5 & 0.030627 & 1.0265 & 0.3110 & $\begin{array}{l}1.0265 \\
0.3110\end{array}$ \\
\hline
\end{tabular}

From Table 5 results, the cointegrating rank is 1 base on the p- value of trace test since the first null hypothesis that can not be rejected is at rank 1 .

Results of Cointegration Relations

$$
\hat{\beta}=\left(\begin{array}{c}
--000 \\
-0.873 \\
-0.115 \\
-0.003 \\
-0.006 \\
-0.000
\end{array}\right) \text { and } \hat{\alpha}=\left(\begin{array}{c}
----.487 \\
0.861 \\
11.342 \\
34.431 \\
51.287 \\
-199700.724
\end{array}\right)
$$

The above results show that the cointegration relation with restricted constant is

$$
e c_{t}^{M L}=-1.573+G D P-0.873 F P I-0.115 I N R-0.003 I F R-0.006 E N C-0.000 C O P
$$

or

$$
G D P=1.573+0.873 \mathrm{FPI}+0.115 \mathrm{INR}+0.003 \mathrm{IFR}+0.006 \mathrm{ENC}
$$

The equation above can be interpreted as follows: the coefficient 0.873 of the value of Foreign Direct Investment in Nigeria (FPI) is the estimated out put elasticity because Gross Domestic Product (GDP) and Foreign Direct Investment (FPI) both appear in logarithms (Lutkepohl, 2005). For a 1\% GDP increase obtained in Nigeria will induce a similar $0.115 \%$ increase in interest rate(INR), $0.003 \%$ inflation rate(IFR), $0.006 \%$ energy consumption (ENC) and $0.000 \%$ of crude oil production(COP).

VECM (2) Representation: The VECM representation of the VAR 3 model is given in equation below. The complete VECM (2)

Equation can represent as follows:

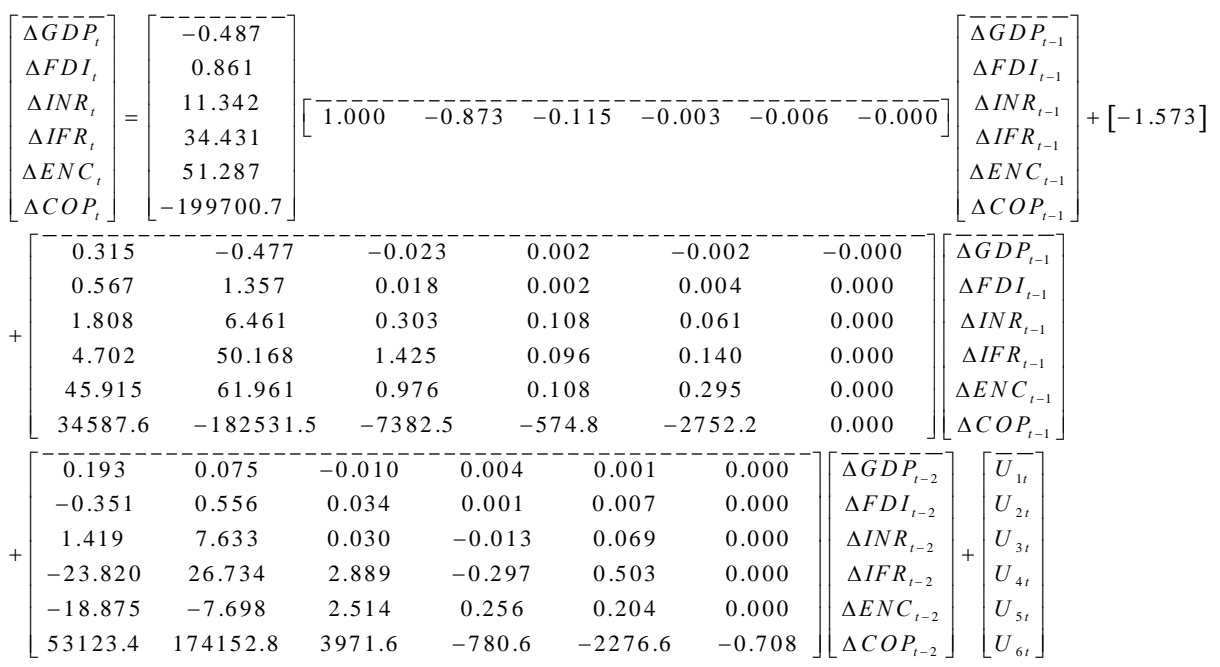


VECM Model Checking: The following tests to the residuals are applied to check for the adequacy of our VECM model (i) the Portmanteau LB test, Godfrey LM test for autocorrelation,(ii)Autoregressive conditional Heteroskedastic LM test for ARCH effect and (ii) Jarque $і ̈$ Bera test for Normality. The results are summarised in Tables 6 and 7 .

The results of Table 6 show that the null hypothesis of no serial autocorrelation and conditional Heteroskedasticity will be accepted for portmanteau LB test and ARCH LM test since there $\mathrm{p}$ - values are greater tahn the significance values of 0.05 and 0.01 for the $5 \%$ and $1 \%$ significant levels. However, null hypothesis is rejected for Godfrey LM Test.

The Table 7 above test also shows that the three of the residuals are normal while the rest are not too far from normality, hence they can be regarded as adequate.

Cusum and Cusum - Sq Test for Stability: These two tests are applied to examine the stability of the long ï run coefficient together with short run dynamic (Pearson and Pearson, 1997).CUSUM and CUSUM SQ test is propose by Brown, Durbin and Evans (1975). The test is applied to the residuals of all variables in the VECM model. If the plot of the CUSUM statistics stays within the critical bound of $95 \%$ level of significance represented by a pair of straight lines drawn at $95 \%$ level of significance the null hypothesis concerning all coefficients in the error correction model cannot be rejected. If any of the lines is crossed. The null hypothesis of coefficient constancy at $95 \%$ level of significance will be rejected. A CUSUM-SQ test is based on the square recursive residuals; a similar procedure is used to carryout the test

Table 6: Results of VECM test for serial correlation and ARCH effect

\begin{tabular}{|c|c|c|}
\hline Residuals & $\mathrm{P} \ddot{\mathrm{i}}$ values & Decisions \\
\hline $\begin{array}{l}\text { Portmanteau LB } \\
\text { Test }\end{array}$ & 0.6997 & Accept \\
\hline Godfrey LM Test & 0.000 & $\begin{array}{l}\text { Reject } \\
\mathrm{H} 0\end{array}$ \\
\hline ARCH LM Test & 0.1168 & $\begin{array}{l}\text { Accept } \\
\text { H0 }\end{array}$ \\
\hline
\end{tabular}

Table 7: Results of VECM Jaque ï Bera and Shapiro - Wilk test for Normality

\begin{tabular}{llll}
\hline \multicolumn{2}{c}{ Jaque ï Bera test } & \multicolumn{2}{c}{ Shapiro ï Wilk test } \\
\hline Residuals & Pï & Pï & Decisions \\
& Value & Value & \\
$\mathrm{U}_{1 \mathrm{t}}$ & 0.0734 & 0.1534 & Accept H0 \\
$\mathrm{U}_{2 \mathrm{t}}$ & 0.0120 & 0.0200 & Rejected H0 \\
$\mathrm{U}_{3 \mathrm{t}}$ & 0.2578 & 0.0875 & Accept H0 \\
$\mathrm{U}_{4 \mathrm{t}}$ & 0.0114 & 0.0123 & Reject H0 \\
$\mathrm{U}_{5 \mathrm{t}}$ & 0.0116 & 0.0110 & Reject H0 \\
$\mathrm{U}_{6 \mathrm{t}}$ & 0.1041 & 0.1632 & Accept H0 \\
\hline
\end{tabular}

Figures 3-4 are a graphical representation of CUSUM and CUSUMSQ plots respectively which are applied to the error correction model selected by the adjusted $\mathrm{R}^{2}$ criterion. CUSUM plots of the variables do not cross critical bounds which indicate that no evidence of any significant instability. However, in CUSUMSQ plot of Fig. 4 three plots slightly cross the critical bound indicating slight instability of these variables.
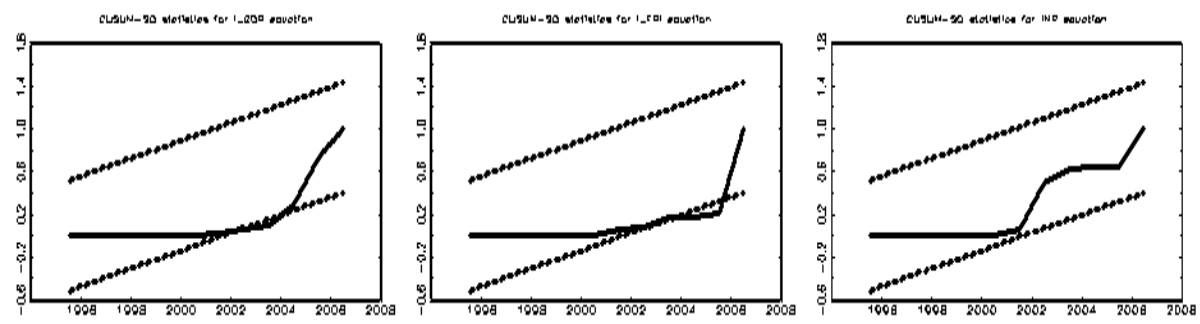

Fig. 3: Plots of Residuals CUSUM 

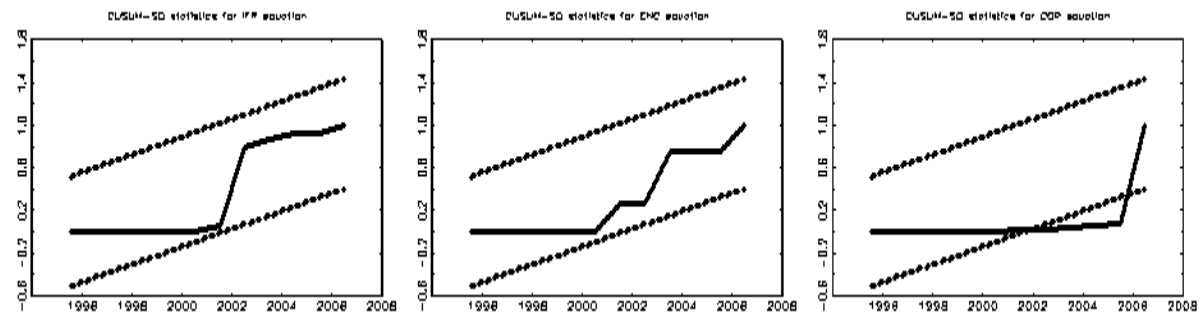

Fig.4: Plots of Residuals CUSUMSQ

Causality Analysis: Results for the analysis of causality are presented and the causality between the variables if any and the direction of the causality of the systems is determined using Granger Causality test. The results of the test are presented in Table 8 . The results estimated show that at 5\% all the variables are Granger ï no causal for GDP. However there is unidirectional causality between FPI and GDP, INR and GDP and, that is what happens between INF and FPI, and ENC and COP. But there is bi $̈$ direction causality between FPI and INR

Table 8: Results of Granger- Causality Analysis

\begin{tabular}{|c|c|c|c|}
\hline Null hypothesis & F- stat & pï value & Decision rule \\
\hline ñGDP does not Granger ï Cause FPIò & 3.9065 & 0.0147 & reject null at $5 \%$ \\
\hline ñFPI does not Granger ï Cause GDPò & 2.0172 & 0.1253 & do not reject null \\
\hline ñGDP does not Granger ï Cause INRò & 0.2556 & 0.8570 & do not reject null \\
\hline ñINR does not Granger ï Cause GDPc̀ & 4.6699 & 0.0062 & reject null \\
\hline ñGDP does not Granger ï Cause IFRò & 0.3776 & 0.7696 & do not reject null \\
\hline ñIFR does not Granger ï Cause GDPò & 1.6534 & 0.1909 & do not reject null \\
\hline ñGDP does not Granger ï Cause ENCò & 1.100 & 0.3592 & do not reject null \\
\hline ñENC does not Granger ï Cause GDPò & 1.2263 & 0.3114 & do not reject null \\
\hline ñGDP does not Granger ï Cause COPò & 0.6025 & 0.6169 & do not reject null \\
\hline ñCOP does not Granger ï Cause GDPò & 0.8270 & 0.4859 & do not reject null \\
\hline ñFPI does not Grander ï Cause INRò & 4.5323 & 0.0075 & reject null \\
\hline ñINR does not Granger ï Cause FPIò & 5.6769 & 0.0022 & reject null \\
\hline ñFPI does not Granger ï Cause IFRc̀ & 8.1395 & 0.0002 & reject null \\
\hline ñIFR does not Granger ï Cause FPIC̀ & 0.9116 & 0.4431 & do not reject null \\
\hline ñFPI does not Granger ï Cause IFRò & 1.4361 & 0.2451 & do not reject null \\
\hline ñENC does not Granger ï Cause FPIò & 0.0723 & 0.9723 & do not reject null \\
\hline ñFPI does not Granger ï Cause COPò & 0.1386 & 0.9364 & do not reject null \\
\hline ñCOP does not Granger Ï Cause FPIò & 0.3057 & 0.8211 & do not reject null \\
\hline ñIFR does not Granger ï Cause INRò & 2.6696 & 0.0591 & do not reject null \\
\hline ñINR does not Granger ï Cause IFRò & 2.9830 & 0.0414 & reject null at $5 \%$ \\
\hline ñENC does not Granger Ï Cause COPC̀ & 5.4392 & 0.0029 & reject null \\
\hline ñCOP does not Granger ï Cause ENCò & 2.0792 & 0.1167 & do not reject null \\
\hline ñENC does not Granger ï Cause IFRò & 1.8644 & 0.1496 & do not reject null \\
\hline ñIFR does not Granger ï Cause ENCc̀ & 1.2775 & 0.2938 & do not reject null \\
\hline ñENC does not Granger ï Cause INRò & 0.2865 & 0.8349 & do not reject null \\
\hline ñINR does not Granger ï Cause ENCc̀ & 0.0148 & 0.9975 & do not reject null \\
\hline
\end{tabular}

\section{CONCLUSION}

In this study we have presented an analysis of the cointegtation between the Foreign Direct Investment (FDI) and Growth Domestic Product
(GDP) with four other macroeconomic variables in Nigeria using the data obtained from central bank statistical Bulletin 2005 for the period of 1970 to 2004. The ADF Test, ADF ï GLS Test 
and KPSS test shows that all the six variables are integrated of order one. VAR 3 and VECM 2 model are chosen base on Akaike criterion the johansen test show that VECM 2 has a cointegration relationship with rank of 1 .

Further the Granger Causality Analysis shows a unidirectional causal relationship between GDP and FDI this is inline with other studies of Basu et al.(2003) and with four other macro economic variables. The results support the theoretical contention and give strong support to the hypothesis that FDI inflows have impact on GDP.

In conclusion, our econometric estimates of the impact of FDI on GDP model for Nigeria suggest that there exists a long run relationship between FDI, and GDP. Precisely, these findings suggest that the contribution of FDI to Nigerianôs economic growth is about 0.873 and all other variables have long run relationship with positive contribution in the growth model except IFR which has negative impact as expected Uremadu (2008).

\section{RECOMMENDATIONS}

The following recommendations were made

a) Having established the fact that foreign direct investment has positive impact on growth domestic product, government should strategize policies that would enhance foreign direct investment in Nigeria.

b) Foreign Direct investment should be seen, not as an end in itself, but as a means of supporting other development initiatives such as poverty reduction or the Millennium Development Goals.

c) Government should target the foreign investors which are most likely to respond, such as the national Diasporas.

\section{REFERENCES}

Adeolu, B.A. (2007). FDI and Economic Growth: Evidence from Nigeria. AERC Research paper 165. African Economic Research Consortium, Nairobi, Kenya.

Adelegan, J.O. (2000). Foreign direct investment and economic growth in Nigeria: A seemingly unrelated model. African Review of Money, Finance and Banking, Supplementary issue of ñ́Savings and Developmentò 2000:5ï 25. Milan, Italy.
Akaike, H. (1974). New look at thestatistical model identification, Institute of statistical mathematics, Minato-ku, Japan

Akinlo, A. (2004). FDI and Economic Growth in Nigeria. An Empirical Investigation. J. Policy Modeling 26: 627-639.

Ariyo, A. (1998). Investment and Nigeriaôs economic growthò. In Investment in the Growth. Process Proceedings of Nigerian Economic Society Annual Conference 1998: 389ï 415. Ibadan, Nigeria.

Barnhill, T.M., Joutz, F.L. and Maxwell, W.F. (2000). Factors affecting the yields on non-investment grade bond indices: A cointegration analysis. J. Empirical Fin. 7: 57 ï 86.

Basu, P., Chakraborty, C. and Reagle, D. (2003). Liberalization, FDI, and Growth in Developing Countries: A Panel Cointegration Approach. Econ. Inquiry, 41:510-16.

Brown, R. L., Durbin, J., and Evans, J. M. (1975), óTechniques for Testing the Constancy of Regression Relationships over Timeâ J. Royal Statis. Soc., Series B, 39: $107 і ̈ 113$.

Caves, R.E. (1996). Multinational Enterprise and Economic Analysis. 2nd edn. Cambridge: Cambridge University Press.

CBN (2005). Statistical Bulletin. Central Bank of Nigeria, Volume 16 @ www.cenbank.org.

Choe, J.I. (2003). Do foreign direct investment and gross domestic investment promote economic growth? Rev. Dev. Econ. 7: 4457.

Chowdhury, A. and Mavrotas, G. (2003). FDI \& growth: What causes what? Paper presented at the UNU/WIDER conference on Sharing Global Prosperity, September 2003, Helsinki, Finland.

De Mello, L.R. (1999). Foreign direct investment-led growth: Evidence from time series and panel data. Oxford Econ. Papers, 51: 133-151.

Dickey, D.A., and Fuller, W.A. (1979). Distribution of the Estimators for Autoregressive Time Series with a Unit Root. J. Am. Statis. Assoc. 74: 10571072.

Edward, J.H and Quinn, B.G. (1979). The determination of the order of an autoregression. J. Royal Statis. Soc. Series B 41: $190\{195$. 
Engle, R.F. (1982). Autoregressive conditional Hetroscedasticity with Estimates of the variance of united kingdoms inflations, Econometrica. 50: 987 ï 1007.

Engle, R.F. and Granger, C.W.J (1987). Cointegration and error correction: Representation, estimation and testing. Econometrica 55: 251-276.

Gideon, S. (1978). Estimating the dimension of a model. The Annals Statis. 6: 461- 464.

Granger, C.W.J.(1969) Investing Causal Relations by Econometric Models and cross- Spectral methods. Econometrica 37: 424-438.

Granger, C.W.J. (1981). Some properties of time series data and their use in econometric model specification, $J$. Econometrics 23: 121-130.

Johansen, S. (1991). Estimation and hypothesis testing of cointegrating vector in Gaussian vector autoregression models. Econometrica 59: 1551 ï 1580.

Lutkepohl, H. (1991). Introduction to Multiple Time Series Analysis, Berlin: Springer Verlag.

Lutkepohl, H. (2005). New Introduction to Multiple Time Series Analysis, Berlin: Springer, Verlag.
MacDonald, R. and Power, D. (1995). Stock prices, dividends and retention: Longterm relationships and short-term dynamics. J. Empirical Finance 2: 135ï 151.

Odozi, V.A. (1995). An Overview of Foreign Investment, 1960-65. CBN Research Department Occasional Paper, No. 11 (June)

Oyinlola, O. (1995). External capital and economic development in Nigeria (1970ї 1991). The Niger. J. Econ. Soc. Stud. 37(2\&3): 205ї 222.

Pesaran, M. H. and Pesaran, B. (1997). Working with Micro t 4.0: Interactive Econometric Analysi Oxford University Press, Oxford.

Phillips, P.C.B. and Perron, P. (1988). Testing for a Unit Root in Time Series Regression, Biometrika, 75: $335 і ̈ 346$.

Toda, H.Y. and Yamamoto, T. (1995). Statistical Inference in Vector Autoregressions with Possible Integrated Processes. J. Econometrics 66: 225-250.

Zhang, K.H. (2001). Does foreign direct investment promote economic growth? Evidence from East Asia and Latin America, Contemp. Econ. Policy, 19: 175-185. 